\title{
Reply on "Constriction of the ductus arteriosus, severe right ventricular hypertension, and a right ventricular aneurysm in a fetus after maternal use of a topical treatment for striae gravidarum"
}

Received: 6 December 2016; Accepted: 21 December 2016; First published online: 6 March 2017

We read with great interest the brief report of Dr Hayes concerning the unfortunate fetal constriction of the ductus arteriosus of a single male infant that the author associated with use of topically applied Bio-Oil ${ }^{\circledR}{ }^{1}$ This is very surprising for us as Bio-Oil ${ }^{\circledR}$ has a long, safe history of use for the treatment of scars and striae and is widely used - it has been marketed in South Africa for 29 years and globally for 14 years, and last year alone over 19 million units were sold. In addition, all ingredients for cosmetic products are considered safe for their intended purpose and are reviewed by the Cosmetic Ingredient Review Expert Panel. Equally, there is no evidence for significant delivery of topical ingredients to the blood stream from cosmetic products, and as a result the systemic health risk is negligible. ${ }^{2}$

The author pointed out that polyphenols contained in certain foods, herbs, and teas may be implicated in fetal ductus arteriosus, and research has shown that their restriction from the diet is helpful. ${ }^{3-7}$ Dr Hayes assumes that Bio-Oil ${ }^{\circledR}$ contains polyphenols, and concludes that Bio-Oil ${ }^{\circledR}$ is associated with the medical condition. In our opinion, however, Dr Hayes' conclusion is based on the erroneous assumption that polyphenols are present in Bio-Oil ${ }^{\circledR}$. Dr Hayes cites the literature that shows that polyphenols are present in general botanical extracts; however, polyphenols are water soluble, and as only essential oils of Lavandula angustifolia oil, Rosmarinus officinalis leaf oil, and Anthemis nobilis flower oil are used in Bio-Oil ${ }^{\circledR}$, and the Calendula officinalis extract is produced by extraction in soybean oil, there are no polyphenols in the product. ${ }^{8-21}$ It also bears mentioning that the essential oils and the $C$. officinalis extract in soybean oil included in the Bio-Oil ${ }^{\circledR}$ formulation together account for $<0.2 \%$ of the product.

Correspondence to: A. V. Rawlings, PhD, FRSB, FRSC, AVR Consulting Ltd Northwich, Cheshire, United Kingdom. Tel: +44 160635 4535; E-mail: TonyRawlings@AVRConsultingLtd.com
As Dr Hayes reports, the mother denied intake of excessive quantities of polyphenol-rich foods and beverages, but their total restriction from the diet was not controlled. If, as the author believes, this particular case is caused by polyphenols, then, in our opinion, it is still more likely to be a result of these substances in the diet, than from use of an anhydrous topical product such as Bio-Oil ${ }^{\circledR}$.

\section{Acknowledgements}

This work is fully funded by Union Swiss.

\section{Conflicts of Interest}

A.V.R. and A.D. are both consultants to Union Swiss the manufacturer of Bio-Oil ${ }^{\circledR}$. P.D. is an employee of Union Swiss.

$$
\begin{array}{r}
\text { Anthony V. Rawlings } \\
\text { AVR Consulting Ltd, Northwich, Cheshire, United } \\
\text { Kingdom } \\
\\
\text { Anthony Dweck } \\
\text { Dweck Data, 8 Merrifield Road, Ford, Salisbury, } \\
\text { Wiltshire, United Kingdom } \\
\text { Paula Dugmore } \\
\text { Union Swiss, } 66 \text { Long Street, Cape Town, South Africa }
\end{array}
$$

\section{References}

1. Hayes DA. Constriction of the ductus arteriosus, severe right ventricular hypertension, and a right ventricular aneurysm in a fetus after maternal use of a topical treatment for striae gravidarum. Cardiol Young 2016; 26: 796-798.

2. Nohynek GJ, Meuling WJ, Vaes WH, et al. Repeated topical treatment, in contrast to single oral doses, with vitamin A-containing preparations does not affect plasma concentrations of retinol, retinyl esters or retinoic acids in female subjects of child-bearing age. Toxicol Lett 2006; 163: 65-76. 
3. Zielinsky P, Piccoli AL Jr, Manica JL, Nicoloso LH. New insights on fetal ductal constriction: role of maternal ingestion of polyphenolrich foods. Expert Rev Cardiovasc Ther 2010; 8: 291-298.

4. Zielinsky P, Piccoli AL Jr, Manica JL, et al. Maternal consumption of polyphenol-rich foods in late pregnancy and fetal ductus arteriosus flow dynamics. J Perinatol 2010; 30: 17-21.

5. Zielinsky P, Piccoli AL Jr, Manica JL, et al. Reversal of fetal ductal constriction after maternal restriction of polyphenol-rich foods: an open clinical trial. J Perinatol 2012; 32: 574-579.

6. Zielinsky P, Piccoli AL Jr, Vian I, et al. Maternal restriction of polyphenols and fetal ductal dynamics in normal pregnancy: an open clinical trial. Arq Bras Cardiol 2013; 101: 217-225.

7. Hahn M, Baierle M, Charao MF, et al. Polyphenol-rich food general and on pregnancy effects: a review. Drug Chem Toxicol 2016; 1-7.

8. Verma RS, Rahman LU, Chanotiya CS, et al. Essential oil composition of Lavandula angustifolia Mill. cultivated in the mid hills of Uttarakhand, India. J Serb Chem Soc 2010; 75: 343-348.

9. Hamad KJ, Al-Shaheen SJA, Kaskoos RA, Ahamad J, Jameel M, Mir SR. Essential oil composition and antioxidant activity of Lavandula angustifolia from Iraq. Int Res J Pharm 2013; 4: 117-120.

10. Jianu C, Pop G, Gruia AT, Horhat FG. Chemical composition and antimicrobial activity of essential oils of Lavender (Lavandula angustifolia) and Lavandin (Lavandula $x$ intermedia) grown in western Romania. Int J Agric Biol 2013; 15: 772-776.

11. Tomescu A, Rus C, Pop G, et al. Chemical composition of Lavandula angustifolia $L$. and Rosmarinus officinalis $L$. essential oils cultivated in west Romania. Res J Agric Sci 2015; 47: 246-253.

12. Genena AK, Hense H, Smania Junior A, Souza SM. Rosemary (Rosmarinus officinalis) - a study of the composition, antioxidant and antimicrobial activities of extracts obtained with supercritical carbon dioxide. Cienc Tecnol Aliment Campinas 2008; 28: 463-469.

13. Jamshidi R, Afzali Z, Afzali D. Chemical composition of hydrodistillation essential oil of Rosemary in different origins in Iran and comparison with other countries. American-Eurasian J Agric Environ Sci 2009; 5: 78-81.

14. Derwich E, Benziane Z, Chabir R. Aromatic and medicinal plants of Morocco: chemical composition of essential oils of Rosmarinus offcinalis and Juniperus phoenicea. Int J Appl Biol Pharm Technol 2011; 2: 145-153.

15. Chahboun N, Esmail A, Rhaiem N, et al. Extraction and study of the essential oil Rosmarinus officinalis Cuellie in the region of Taza, Morocco. Der Pharma Chemica 2014; 6: 367-372.

16. Muley BP, Khadabadi SS, Banarase NB. Phytochemical constituents and pharmacological activities of Calendula officinalis Linn (Asteraceae): a review. Trop J Pharm Res 2009; 8: 455-465.

17. Wagner S, Pfleger A, Mandl M, Bochzelt H. Changes in the qualitative and quantitative composition of essential oils of clary sage and roman chamomile during steam distillation in pilot plant scale. In Zereshki S, (ed) Distillation - Advances from Modelling to Applications. InTech, Croatia, 2012: $141-158$.

18. Butnariu M, Coradini CZ. Evaluation of biologically active compounds from Calendula officinalis flowers using spectrophotometry. Chem Cent J 2012; 6: 1-7.

19. Khalid KA, Teixeira da Silva JA. Biology of Calendula officinalis Linn: Focus on pharmacology, biological activities and agronomic practices. In: Medicinal and Aromatic Plant Science and Biotechnology. Global Science Books, 2011, 12-27. Available at www.globalsciencebooks.info/Online/GSBOnline/images/.../ MAPSB_6(1)12-27o.pdf

20. Srivastava JK, Shankar E, Gupta S. Chamomile: a herbal medicine of the past with bright future. Mol Med Rep 2010; 3: 895-901.

21. Sharafzadeh S, Alizadeh O. Geraman and Roman chamomile. J Appl Pharm Sci 2011; 1: 1-5. 